УДК 347.19

DOI https://doi.org/10.32838/TNU-2707-0581/2021.6/05

\title{
Яворовенко Н.М.
}

Донецький національний університет імені Василя Стуса

\section{ОКРЕМІ ІСТОРИЧНІ АСПЕКТИ ЗАРОДЖЕННЯ ПІДПРИЕМНИЦЬКОЇ ДІЯЛЬНОСТІ ТА РОЛЬ ФРАНЦІЇ В ЦЬОМУ ПРОЦЕСІ}

У статті висвітлюються питання зародження підприємницької діяльності у світі загалом та Франиї зокрема. Окремо визначено роль Франиї в иьому процесі. Автором розкрито зміст категорії «підприємець»» та встановлено засновника изього терміна - Річарда Кантильона.

Викладено позииї інших видатних науковиів із иього питання (Бодо, Френсіса Вокера, Девіда, Пітера Друкера, Альберта Шапіро, Роберта Хизрича). Охарактеризовано основні принщипи підприємництва.

Також у статті розглядаються історичні аспекти запровадження у Франиії господарського законодавства другої половини XVII століття. Розкрито правовий режим суб'єктів господарювання, що провадять підприємницьку діяльність за нормами франиузького законодавства. Окремо з'ясовано поняття «постійне представництво», що відображсається в комериійному законодавстві Франиії.

Висвітлюється поняття «комерсант»-той, хто здійснює комериійні дії; особа, яка здійснює купівлю товару з метою його подальшого перепродажу. Також у статті зазначено, щз законодавчий франиузький термін «агент» визначає особу, яка провадить комериійну діяльність від імені підприємия. Вони не мають статусу підприємщів, якще вони не здійснюють операчії за власний рахунок чи не провадять торговельну діяльність.

3'ясовано, що генеральний директор суб 'єкта господарювання у Франиії-ие керівник компанії, у підпорядкуванні якого перебувають директори та керівники акціонерних товариств, а також менеджери. Відповідно до франиузьких приписів торговими представники є працівники, які пов'язані трудовим договором, але не є торговиями, як їхні роботодавиі.

До суб'єктів підприємницької діяльності законодавство Франції зараховує і мікропідприємство. Воно утворюється для здійснення комериійної, ремісничої або незалежної підприємницької діяльності.

Також у статті висвітлюється і роль малих підприємств у здійсненні підприємнищької діяльності у Франщії. Розкрито статистичні показники щцодо провадження підприємнищтва (починаючи з 2015 року). У прикінцевій частині статті надано авторський висновок із иієеі тематики.

Ключові слова: підприємництво, підприємець, господарське законодавство, постійне представництво, комерсант, мікропідприємство, мале підприємство.

Постановка проблеми. Спільне проживання людей не можна уявити без виробництва різноманітних матеріальних благ для задоволення не лише індивідуальних, а й групових та інших категорій спільних інтересів. Господарювання (у розумінні задоволення господарських потреб (в одязі, житлі, предметах побуту тощо) певних соціальних груп) притаманне людській спільноті ще на ранніх етапах розвитку суспільства. Водночас функціонування будь-якої людської спільноти не $\epsilon$ можливим без регулювання відносин між іiї членами.

Бурхливий розвиток ремесл і торгівлі в епоху середньовіччя (у приморських містах, пов'язаних із торгівлею з іншими територіями та державами) сприяв розвитку спеціального регулювання цієї сфери (спочатку у формі торгових звичаїв, рішень судів зі справ між торговцями, збірок таких звичаїв та суддівських рішень (наприклад, «Збірник морського права Ганзи»), а згодом як ухвалення кодифікованих нормативно-правових актів).

Аналіз останніх досліджень і публікацій. Висвітлені в статті актуальні питання частково знайшли своє відображення в роботах вітчизняних та закордонних учених (І.Г. Андрущенка, О.Л. Ануфрієвої, О.М. Вінник, Г.М. Колісник, Г.М. Лагоцької, Т.Г. Пальчевської, В.С. Щербини та ін.). 
Постановка завдання. Мета статті - розкрити історичні аспекти зародження підприємницької діяльності та визначити роль Франції в цьому процесі.

Виклад основного матеріалу дослідження. Термін «підприємець» був уведений французьким економістом Річардом Кантильоном на початку XVIII ст. Під ним розумілася людина, яка бере на себе ризик, пов'язаний 3 організацією господарської діяльності або розробкою нової ідеї, нової продукції чи нового виду послуг, що пропонується громаді. Він визначав підприємця як людину, яка за певну ціну купує засоби виробництва, щоб виробити товар і продати його з метою отримання прибутку, і яка, беручи на себе зобов'язання щодо витрат, не знає, за якими цінами може їх реалізувати.

Згодом його послідовники вдосконалювали та доопрацьовували бачення терміна «підприємець». Зокрема:

- Бодо (1797 рік): «Підприємець - це особа, яка несе відповідальність за підприємницьку справу; той, хто планує, контролює, організовує»;

- Френсіс Вокер (1876 рік): «Слід розрізняти тих, хто надає капітал і отримує за нього відсотки, i тих, хто отримує прибуток завдяки своїм організаторським здібностям»;

- Девід (1961 рік): «Підприємець - це енергійна людина, яка діє в умовах помірного»;

- Пітер Друкер (1964 рік): «Підприємець - це людина, яка використовує будь-яку можливість 3 максимальною вигодою»;

- Альберт Шапіро (1975 рік): «Підприємець - це людина, яка виявляє ініціативу, організовує соціально-економічний механізм. Діючи в умовах ризику, вона несе повну відповідальність за можливу невдачу»;

- Роберт Хизрич (1985 рік): «Підприємництво - це створення чогось нового, що має вартість, а підприємець - це людина, яка витрачає на все це необхідний час і сили, бере на себе весь фінансовий, психологічний ризик, отримуючи як винагороду гроші та задоволення від досягнутого» $[1$, с. 12$]$.

Узагальнюючи представлені погляди вказаних науковців, можна констатувати, що сфера підприємництва грунтується на таких основних принципах, як:

- вільний вибір видів діяльності;

- залучення на добровільних засадах до здійснення підприємницької діяльності майна та коштів юридичних осіб і громадян;
- самостійне формування програми діяльності та вибір постачальників і споживачів продукції, що виробляється, встановлення цін відповідно до законодавства;

- вільний найм працівників;

- залучення та використання матеріальнотехнічних, фінансових, трудових, природних та інших видів ресурсів, використання яких не заборонено або не обмежено законодавством;

- вільне розпорядження прибутком, що залишається після внесення платежів, установлених законодавством;

- самостійне здійснення підприємцем (юридичною особою) зовнішньоекономічної діяльності, використання будь-яким підприємцем належної йому частки валютної виручки на свій розсуд [2, с. 210].

Варто підкреслити, що 3 Францією другої половини XVII ст., за часів правління Людовіка XIV, пов'язується перша спроба кодифікації норм торгового права. Ініціатором кодифікації був міністр фінансів Кольбер, ім'я якого отримали такі два ордонанси ${ }^{1}$, як Ордонанс про торгівлю 1673 p. і Ордонанс мореплавства 1681 р. Завдяки ордонансам Кольбера, що згодом стали основою Торгового кодексу Наполеона 1807 р., на території Франції уніфіковано правове регулювання торговельних операцій.

Нині правовий режим суб'єктів господарювання, що провадять підприємницьку діяльність, визначається нормами Комерційного кодексу Франції. Так, у французькому комерційному законодавстві $є$ поняття «постійне представництво», що означає постійне місце діяльності, через яке повністю чи частково провадиться підприємницька діяльність суб'єкта господарювання.

Термін «постійне представництво», зокрема, включає:

1) а) місце управління; b) відділення; с) контору; d) фабрику; е) майстерню; f) шахту, нафтову або газову свердловину, кар'єр або будь-яке інше місце видобутку природних ресурсів; g) постійне місце, яке використовується як торгова точка;

2) а) будівельний чи монтажний майданчик або складальний об'єкт вважаються постійним представництвом лише в тому разі, якщо вони існують більше дванадцяти місяців; b) установка чи споруда, що використовується для розвідки природних ресурсів, створює постійне представництво, якщо таке використання триває більше шести місяців;

' Указ короля або інше рішення у Франції, що має силу закону. 
3) незважаючи на попередні положення цієї статті, термін «постійне представництво» не передбачає: а) використання споруд виключно 3 метою зберігання, демонстрації або поставки товарів чи виробів, що належать підприємству; b) утримання запасів товарів або виробів, що належать підприємству, виключно з метою зберігання, демонстрації або поставки; с) утримання запасів товарів або виробів, що належать підприємству, виключно з метою переробки іншим підприємством; d) утримання постійного місця діяльності виключно з метою закупівлі товарів чи виробів або для збирання інформації для підприємства; е) утримання постійного місця діяльності виключно 3 метою здійснення для підприємства будь-якої іншої діяльності підготовчого чи допоміжного характеру; f) утримання постійного місця діяльності виключно для здійснення будьякої комбінації видів діяльності, перелічених у підпунктах від а) до е), за умови, що сукупна діяльність постійного місця діяльності, яка виникає внаслідок такої комбінації, має підготовчий чи допоміжний характер [3].

Також у французькому законодавстві має місце поняття «комерсант» - той, хто здійснює комерційні дії, як-от особа, яка здійснює купівлю товару 3 метою його подальшого перепродажу. Термін «комерсант» походить від комерційного акта та передбачає: а) застосування конкретних норм до відповідної діяльності; б) кваліфікацію особи, яка їі здійснює. Типовим прикладом комерсанта $\epsilon$, наприклад, той, хто купує товари в оптового продавця, щоб перепродати їх особам у власній крамниці.

За вимогами французького законодавства, щоб бути підприємцем, останній має здійснювати самостійно, ініціативно, систематично, на власний ризик діяльність та передбачати отримання прибутку.

Особи, які не користуються незалежністю у повній мірі, навіть беручи участь у здійсненні комерційної діяльності, не є підприємцями в юридичному розумінні цього поняття. На цьому підгрунті у французькому законодавстві має місце поняття «агент» - особа, яка провадить комерційну діяльність від імені підприємця. Комерційні агенти не мають статусу підприємців, якщо вони пов'язані лише мандатним контрактом 3 одним або кількома підприємствами, яких вони представляють, якщо вони не здійснюють операції за власний рахунок чи не провадять торговельну діяльність [4].

Згідно 3 приписами французького законодавства генеральний директор суб'єкта господарю- вання - це керівник компанії, у підпорядкуванні якого перебувають директори та керівники акціонерних товариств, а також менеджери. Вони мають можливість провадити комерційну діяльність від імені компанії. Водночас вони не $\epsilon$ підприємцям, оскільки не провадять комерційну діяльність від власного імені. Отже, самі працівники підприємства не $є$ торговцями, коли вони здійснюють діяльність від імені компанії, перебуваючи в безпосередньому підпорядкуванні своїх роботодавців. У цьому разі роботодавці можуть мати статус підприємців.

Слід зазначити, що торгові представники - це працівники, які пов'язані трудовим договором, але не $\epsilon$ торговцями, як їхні роботодавці.

Згідно 3 нормами законодавства Франції різниця між комерційними агентами та торговими представниками полягає в тому, що комерційні агенти пов'язані з компанією не трудовим договором, а агентським. Це пояснює те, чому партнери комерційної компанії не є торговцями, оскільки вони не займаються торгівельною діяльністю. Цей юридичний статус має лише компанія, в підпорядкуванні якої вони перебувають.

Французьке законодавство до суб' єктів підприємницької діяльності зараховує і мікропідприємство. Воно утворюється для здійснення комерційної, ремісничої або незалежної підприємницької діяльності. Закон дозволяє поєднувати статус мікропідприємця з іншим статусом (працівника, безробітного, державного службовця, фермера, пенсіонера чи студента). Цьому статусу має відповідати спрощена процедура декларування доходів та сплати податків [5].

Досить поширеним явищем у Франції є діяльність малих підприємств. Так, нині у Франції до категорії малих належать такі, на яких працює менше 50 найманих працівників.

Нині 33 млн малих підприємств, що існують у Франції, близько 1,5 млн належить до індивідуального або сімейного бізнесу й обходиться взагалі без найманого персоналу, а на 1200 тис. підприємств працюють менше ніж по 10 осіб. Доходи фірм і компаній малого бізнесу не мають чітких законодавчих обмежень. Можна лише констатувати, що в середньому доходи малих підприємств коливаються від 10 до 100 тис. євро на рік. Ураховуючи те, що станом на 1 січня 2015 року населення Франції становило 65073482 осіб, то на 10000 населення припадає 461 мале підприємство, що є одним із найвищих показників серед країн - членів Європейського Союзу. 
Частка найманих працівників малого бізнесу у Франції становить 59\% від усіх найманих працівників, а частка реалізованої продукції, вироблена найманими працівниками малого бізнесу, становить понад 64\% від реалізації валової продукції у Франції.

У Франції застосовуються спеціальні (спрощені) податкові режими для малих та середніх підприємств залежно від величини обороту. Такі підприємства не подають декларації про податок на додану вартість, проте виплачують прибуткові податки, рівень яких залежить від сфери діяльності (торговельні операції, послуги тощо).

Діяльність малих підприємств у Франції суттєво змінилася за останні декілька десятиріч. До цього часу невеликі виробничі підприємства становили архаїчний сегмент ринку, бо їхні власники могли дозволити собі придбання лише дешевого чи застарілого обладнання. Сьогодні ситуація якісно інша. Сучасні малі підприємства, особливо у виробничій сфері, працюють із високими технологіями. У більшості випадків це відбувається тому, що великим корпораціям тепер невигідно все виробляти своїми силами. Вони стали співпрацювати на принципах підряду чи субпідряду з більш дрібними підприємствами, які і випускають для промислових гігантів окремі комплектувальні частини. При цьому великі підприємства на комерційній основі допомагають дрібним фірмам обладнанням, сировиною, переданням технологій тощо [6, с. 180].

Нині у Франції зареєстровано близько 3 млн малих підприємств. Із них 1500000 працює у сфері послуг, 780 тис. - торгівлі, 350 тис. будівництва, 303 тис. - промисловості. Це класична структура постіндустріальної економіки. Щорічно в країні відкривається близько 250 тис. малих підприємств, а банкрутує 50 тис. При цьому 40-50\% нових робочих місць, створюваних у Франції, припадає саме на діяльність малих підприємств [7].

Серед країн - членів Європейського Союзу Франція користується заслуженою популярністю як країна високого життєвого рівня населення, надійної особистої безпеки та соціальної захищеності громадян. Франція є однією з найбільш розвинених індустріально-аграрних країн світу. Її валовий національний продукт (далі - ВНП) оцінюється приблизно в 1500 млрд дол. США. За цим показником вона посідає 5-е місце у світі, а за розміром ВНП на душу населення їй належить 4-е місце (26,7 тис. дол. США). За обсягом промислового виробництва Франція посідає 5-е місце, поступаючись США, Японії, Німеччині та Великій Британії. Промисловість створює близько $25 \%$ ВНП, забезпечує близько третини робочих місць. Її основними галузями $є$ такі: машинобудівна, хімічна, сталеливарна, авіакосмічна, автомобілебудівна, електроніка, суднобудування, гірничорудна, металургія, текстильна, атомна енергетика, радіоелектроніка, харчова. За обсягом сільськогосподарського виробництва Франція посідає 3-є місце у світі, поступаючись лише США та Канаді [8].

Висновки. Наприкінці статті можемо констатувати, що Францією накопичено достатній досвід стосовно створення суб'єктів господарювання та здійснення ними підприємницької діяльності. Однією з найпоширеніших форм здійснення підприємницької діяльності $€$ постійне представництво, що передбачає досить велику кількість суб'єктів підприємництва. Також поширеним у Франції є використання категорії «мікропідприємства» та похідного від нього терміна «мікропідприємець». Загалом, французьке законодавство щодо створення та діяльності підприємницьких структур є досить ліберальним та заслуговує на детальне вивчення з метою можливої імплементації у вітчизняне законодавство.

\section{Список літератури:}

1. Ануфрієва О.Л., Пальчевська Т.Г., Лагоцька Г.М Підприємницька діяльність : навчальний посібник / за наук. ред. О.Л. Ануфрієвої. Івано-Франківськ : Лілея-НВ, 2014. 304 с.

2. Колісник Г.М. Сутність суб'єктів та видів господарської діяльності. Вісник Хмельницького наиіонального університету. 2010, № 5, Т. 4 С. 207-214.

3. Конвенція між Урядом України і Урядом Французької Республіки про уникнення подвійного оподаткування та попередження податкових ухилень стосовно податків на доходи і майно (Конвенцію ратифіковано Законом № 150/98-BP (150/98-BP) від 03.03.98). URL: https://zakon.rada.gov.ua/laws/show/250_001\#Text.

4. Рішення від 26.02.2008, Господарська палата Касаційного суду / Господарська палата Касаційного суду. 2602. URL: https://gm-avocats.com/.

5. Déclaration de micro-entrepreneur (auto-entrepreneur) / Direction de l'information légale et administrative (Premier ministre). 2021. URL: https://www.service-public.fr/professionnels-entreprises/vosdroits/F23264. 
6. Андрущенко І.Г. Наявні проблеми у сфері здійснення операцій по злиттю і поглинанню публічних акціонерних товариств. Науковий вісник Академії муніципального управління. 2014. Випуск 2. С. 179-183.

7. Дацкевич А.Я. Малий бізнес Франції. URL: https://otherreferats.allbest.ru/international/00748724_0.html.

8. Чухно А.А. Франція в міжнародному поділі праці. URL: https://knowledge.allbest.ru/international/2c0a 65635b3ac78b4c43a89421316c37_0.html.

\section{Yavorovenko N.M. SOME HISTORICAL ASPECTS OF THE ORIGIN OF BUSINESS AND THE ROLE OF FRANCE IN THIS PROCESS}

The article covers issues related to the emergence of entrepreneurial activity in the world in general and France in particular. The role of France in this process is separately defined in the work. The author reveals the content of the category "entrepreneur" and identifies the originator of this term, Richard Cantillon.

The positions of other prominent scholars on this issue are presented, in particular: Bodo, Francis Walker, David, Peter Drucker, Albert Shapiro, Robert Khizrich. The basic principles of entrepreneurship are described.

The article also considers the historical aspects of the introduction of economic legislation in France in the second half of the XVII century. The legal regime of business entities engaged in business activities under French law is disclosed. The concept of "permanent establishment", which is reflected in the commercial legislation of France, is clarified separately.

The concept of "merchant" - the one who carries out commercial activities; the person who buys the goods for resale. The article also states that the French legal term "agent" defines a person who carries out commercial activities on behalf of an entrepreneur. They do not have the status of entrepreneurs if they do not carry out operations at their own expense or do not carry out trade activities.

It has been established that the CEO of a business entity in France is the head of the company, which is responsible for the directors and managers of joint stock companies, as well as managers. According to French regulations, sales representatives are employees who are bound by an employment contract but are not traders like their employers.

French law also includes micro-enterprises as business entities. It is formed for commercial, craft or independent business activities.

The article also highlights the role of small businesses in doing business in France. Statistical indicators on entrepreneurship starting from 2015 are revealed. In the final part of the article the author's conclusion on this subject is given.

Key words: entrepreneurship, entrepreneur, economic legislation, permanent establishment, merchant, micro enterprise, small enterprise. 